\title{
Evaluation of strategy for testing thyroid function applied to hypothyroidism
}

\author{
CATHYRYN M CORNS, AL MILLER \\ From the Courtauld Institute of Biochemistry, Middlesex Hospital Medical School, London
}

SUMMARY A strategy for testing thyroid function with discretionary assay of thyroid stimulating hormone (TSH) following initial measurement of total plasma thyroxine $\left(\mathrm{tT}_{4}\right)$ was retrospectively evaluated in relation to the diagnosis of primary hypothyroidism. Over a two year period $14641 \mathrm{tT}_{4}$ assays were done and 6887 TSH assays, of which $29 \%$ were initiated in the laboratory. The percentage of raised TSH values (over $5 \mathrm{mU} / \mathrm{l}$ ) was similar to those for clinician and pathologist initiated requests $(23 \cdot 2 \%$ and $23 \cdot 6 \%)$.

Some TSH requests (1620) were cancelled; when 212 of these were subsequently analysed the TSH value was raised in $5.7 \%$. The incidence of raised $\mathrm{TSH}$ values in 188 patients with a $\mathrm{tT}_{4}$ below 100 $\mathrm{nmol} / 1(7 \cdot 8 \mu \mathrm{g} / 100 \mathrm{ml})$, in whom TSH was not requested, was $5 \cdot 3 \%$. Most of these raised TSH results could be readily explained by information available to the requesting clinician but not given on the request form.

In February 1983 this department took over the routine thyroid hormone assays for the Middlesex Hospital due to an internal transfer of services. Before undertaking the assays a strategy for testing thyroid function was planned to offer clinicians an efficient service and minimise the costs by avoiding the performance of unnecessary tests. This paper considers the strategy chosen in relation to the investigation of hypothyroidism, its evolution during use, and an investigation of its validity.

\section{Material and methods}

Initially in February 1983 the tests offered routinely were: total thyroxine $\left(\mathrm{tT}_{4}\right)$, total tri-iodothyronine $\left(\mathrm{tT}_{3}\right)$, and thyroid stimulating hormone (TSH). Free thyroxine $\left(\mathrm{fT}_{4}\right)$, thyroxine binding globulin (TBG), thyroid antibodies, and thyroid stimulating immunoglobulins were also available in other departments. In June 1984 the $\mathrm{tT}_{3}$ measurements were replaced by an assay for free $T_{3}\left(\mathrm{fT}_{3}\right)$. Table 1 shows the analytical methods used and the adult reference ranges.

Requests were divided into five main categories:

1 Follow up of known thyroid disease.

Accepted for publication 20 November 1985
2 Clinical suspicion of thyroid disease.

3 Screening (mainly of geriatric admissions).

4 Investigation of pituitary function.

5 The investigation of other conditions in which thyroid disease may be contributory, such as infertility and hypercalcaemia.

THE INITIAL STRATEGY

Total thyroxine was used as the routine thyroid function test applicable to all diagnostic groups; this hormone was measured daily. Total tri-iodothyronine or $\mathrm{fT}_{3}$ was used in the further investigation of hyperthyroidism and TSH in the elucidation of hypothyroidism. When thyroxine, thyroxine combined with some other thyroid related hormone, or "thyroid function tests" were requested, a total $\mathrm{T}_{4}$ was initially measured. The few remaining requests were vetted; inappropriate requests (such as TSH in hyperthyroidism or $T_{3}$ in hypothyroidism) were given a $\mathrm{tT}_{4}$ : for the remainder (usually for TSH measurement after thyrotrophin releasing hormone (TRH) stimulation the tests requested were performed.

When the $\mathrm{tT}_{4}$ result was available all the request forms were examined either by a member of the clinical staff of the department (consultant or senior registrar) or by the non-medical lecturer running the radioimmunoassay section of the laboratory. On the basis of the $\mathrm{tT}_{4}$ result and the clinical information given further tests might be performed whether or not 
Table 1 Analytical methods used for measurement of thyroid hormone

\begin{tabular}{lll}
\hline Hormone & Adult reference range & Method used \\
\hline Total $\mathrm{T}_{4}$ & $60-140 \mathrm{nmol} / 1(4 \cdot 7-10.8 \mu \mathrm{g} / 100 \mathrm{ml})$ & NETRIA \\
Total $_{3}$ & $1 \cdot 2-3 \cdot 5 \mathrm{nmol} / 1(1.85-5.39 \mathrm{ng} / 100 \mathrm{ml})$ & NETRIA \\
Thyroid $^{*}$ stimulating hormone & Amerlex \\
${\text { Free } \mathrm{T}_{3}}^{*}$ & Up to $5 \mathrm{mU} / 1$ & Amerlex \\
\hline
\end{tabular}

*These assays were routinely performed using half the manufacturer's recommended amounts of sample and reagents.

NETRIA: North East Thames Regional Immunoassay Service kit.

Amerlex: Supplied by Amersham International.

they were originally requested, according to broad criteria (Table 2). The information in this Table is obviously not exclusive, and other clinical details were important in deciding the need for further tests: a strong clinical suspicion of hypothyroidism would usually lead to a TSH being done if the $\mathrm{tT}_{4}$ was up to $115 \mathrm{nmol} / 1(8.9 \mu \mathrm{g} / 100 \mathrm{ml})$; on the other hand, indications that a patient was clinically euthyroid meant that a $\mathrm{tT}_{4}$ of $80 \mathrm{nmol} / \mathrm{l}(6.2 \mu \mathrm{g} / 100 \mathrm{ml})$ might be reported without further tests.

In addition to requesting further tests, the chemical pathology staff also cancelled further tests requested by clinicians if these were thought unlikely to provide clinically useful information. All TSH requests with a $\mathrm{tT}_{4}$ exceeding $200 \mathrm{nmol} / \mathrm{l}(15.5 \mu \mathrm{g} / 100 \mathrm{ml})$ were cancelled, unless some specific reason for requiring the test was given, or unless they formed part of a TRH test.

If results were above the $\mathrm{tT}_{4}$ values indicated in the second column of Table 2 the TSH was cancelled, unless there was some special indication. For this purpose two messages were used on the computer generated report forms: "Test not indicated" was used for a definitely irrelevant request, whereas "Discuss if required" was used to indicate that the test did not seem to be required on the basis of the information supplied.
CONSEQUENCES OF THIS STRATEGY

In the two years from February 1983 to January 1985 a total of $14641 \mathrm{tT}_{4}$ analyses were performed. Of $\vec{\sigma}$ these, 6887 samples had both $\mathrm{tT}_{4}$ and $\mathrm{TSH}$ values measured; 4859 of these were requested by clinicians, ? and 2028 were initiated by the laboratory. During the $\omega$ same period 1620 requests for TSH were cancelled; of $\dot{\omega}$ these less than 50 were rerequested by clinicians. At a cost of $£ 1.20$ per TSH request, this represents a saving ${ }_{0}^{\omega}$ in consumables of about $£ 1950$ over the two years.

Of the TSH analyses that were performed, $23 \cdot 2 \% \vec{z}$ of those requested by clinicians were found to be

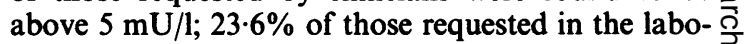
ratory were also above this. The cost of these requests $\vec{P}$ initiated by the laboratory has to be offset against the $\mathscr{\infty}$ potential saving in clinician time, clinic visits, and added convenience to patients.

These findings indicate that resources have been conserved. It was decided, however, that two retrospective studies should be carried out: measurement of TSH values in a representative proportion of the $\stackrel{\mathbb{Q}}{\stackrel{\perp}{2}}$ cancelled requests to ascertain whether the strategy $\overrightarrow{\vec{O}}$ was depriving clinical staff of diagnostic information; $\frac{3}{3}$ and the measurement of TSH on samples, on which only $\mathrm{tT}_{4}$ was requested and only $\mathrm{tT}_{4}$ was measured, to assess whether the limits set for initiating TSH analyses in the laboratory were appropriate.

Table 2 Broad criteria for deciding whether TSH should be measured

\begin{tabular}{|c|c|c|}
\hline \multirow[t]{2}{*}{ Clinical summary } & \multicolumn{2}{|l|}{$t T_{4}$ values $(\mathrm{nmol} / \mathrm{l})$} \\
\hline & No further action & $T S H$ requested \\
\hline $\begin{array}{l}\text { Hypothyroidism, on } \mathrm{T}_{4} \text { for less than three months } \\
\text { Hypothyroidism, on } \mathrm{T}_{4} \text { for more than three months } \\
\text { Last TSH raised } \\
\text { Infertility } \\
\text { Hyperprolactinaemia } \\
\text { Receiving antithyroid treatment } \\
\text { Geriatric screening } \\
\text { Other screening } \\
\text { Pregnant or receiving oestrogens } \\
\text { ? Hypothyroid } \\
\text { ? Hyperthyroid } \\
\text { Previous thyroid surgery } \\
\text { Carcinoma of thyroid } \\
\text { Goitre or Hashimoto's thyroiditis } \\
\text { ? Hypopituitarism } \\
\text { Receiving fenclofenac }\end{array}$ & $\begin{array}{l}\text { above } 150 \\
\text { above } 100 \\
\text { above } 80 \\
\text { above } 150^{*} \\
\text { above } 100^{*} \\
\text { above } 80 \\
\text { above } 120^{*} \\
\text { above } 100^{*} \\
\text { above } 80 \\
\text { above } 100 \\
\text { above } 100 \\
\text { (but TSH requests } \\
\text { above } 100\end{array}$ & $\begin{array}{l}\text { below } 150 \\
\text { below } 100 \\
\text { all } \\
\text { below } 80 \\
\text { all } \\
\text { below } 120 \\
\text { below } 80 \\
\text { below } 80 \\
\text { below } 100 \\
\text { below } 80 \\
\text { below } 80 \\
\text { below } 100 \\
\text { all } \\
\text { below } 100 \\
\text { cancelled) } \\
\text { below } 100 \\
\text { all }\end{array}$ \\
\hline
\end{tabular}


Table 3 Results of TSH analyses performed retrospectively on cancelled requests

\begin{tabular}{|c|c|c|c|c|c|c|c|c|c|c|c|c|c|}
\hline \multirow[t]{2}{*}{ TSH result $(m U / l)$} & \multicolumn{13}{|c|}{ Total thyroxine result (nmol/l) } \\
\hline & $81-90$ & $91-100$ & $101-110$ & $111-120$ & $121-130$ & $131-140$ & $141-150$ & $151-160$ & $161-170$ & $171-180$ & $181-190$ & $191-200$ & Over 200 \\
\hline \multirow{5}{*}{$\begin{array}{c}0 \cdot 1-5 \cdot 0 \\
5 \cdot 1-10 \cdot 0 \\
10 \cdot 1-15 \cdot 0 \\
15 \cdot 1-20 \cdot 0 \\
20 \cdot 1-25 \cdot 0 \\
25 \cdot 1-30 \cdot 0 \\
30 \cdot 1-35 \cdot 0 \\
\text { Over } 35 \cdot 0\end{array}$} & 3 & 22 & 33 & 31 & 33 & 23 & 13 & 13 & 4 & 5 & 9 & 3 & 8 \\
\hline & & & & & 1 & & & & & & & & \\
\hline & & 1 & & & 1 & & & & & & & & \\
\hline & & & 2 & & & & & & & & & & \\
\hline & & & & & 1 & & & & & & & & \\
\hline
\end{tabular}

$\mathrm{tT}_{4} \mathrm{nmol} / \mathrm{l} \times 0.078=\mu \mathrm{g} / 100 \mathrm{ml}$

\section{Results}

\section{RETROSPECTIVE ANALYSIS OF CANCELLED TSH REQUESTS}

The last 212 cancelled TSH requests from 1984 were analysed retrospectively. Of these, 200 results fell within the adult reference range. Table 3 shows the results grouped according to $\mathrm{tT}_{4}$ and $\mathrm{TSH}$ values.

A $5.7 \%$ incidence of cancelled tests lay outside the reference range. As this seemed to be unacceptably high, the case records of these patients were examined to discover whether any of these patients had a known history that could account for the results but which had not been given on the request form. Table 4 lists the relevant patient details that were discovered. Of the 10 patients whose notes were available (the two other cases were samples sent from another hospital), nine had known thyroid problems, which had not been referred to on the request form, and one was receiving stilboestrol. Interestingly five of these requests had been made by a single consultant physician.
TSH ANALYSES ON SAMPLES ON WHICH ONLY TOTAL THYROXINE WAS REQUESTED AND MEASURED

One hundred and eighty eight samples were selected from the $\mathrm{tT}_{4}$ analyses performed in November and December 1984. The only criterion for selection was that the $\mathrm{tT}_{4}$ was below $100 \mathrm{nmol} / 1(7.8 \mu \mathrm{g} / 100 \mathrm{ml})$ and that no further tests had been requested or performed on these samples. Ten samples were found to have a raised value of TSH (above $5 \mathrm{mU} / \mathrm{l}$ ). Table 5 shows these results grouped by $\mathrm{tT}_{4}$ and $\mathrm{TSH}$. Of these results, $5 \cdot 3 \%$ lie outside the reference range. The notes of these patients were examined and Table 6 shows the relevant information discovered.

\section{Discussion}

The retrospective analysis of TSH on samples where requests for this hormone had been cancelled in the laboratory showed that in most cases the decision to cancel tests was valid. In all 10 of the cases where the TSH result was subsequently found to be abnormal

Table 4 Results and clinical information on patients whose TSH was originally cancelled and retrospectively analysed and found to be raised

\begin{tabular}{|c|c|c|c|c|c|}
\hline \multicolumn{6}{|c|}{ Patient details } \\
\hline No & Age and sex & $t T_{4}$ & TSH & Details on form & Information from case notes \\
\hline $\begin{array}{l}1 \\
2\end{array}$ & $\begin{array}{l}71 \mathrm{~F} \\
72 \mathrm{M}\end{array}$ & $\begin{array}{r}99 \\
128\end{array}$ & $\begin{array}{r}9 \cdot 7 \\
20 \cdot 6\end{array}$ & $\begin{array}{l}\text { Diabetes mellitus } \\
\text { Cadmium poisoning, } \\
\text { chronic renal failure }\end{array}$ & $\begin{array}{l}\text { Positive thyroid antibodies } \\
\text { Hypothyroid on thyroxine }\end{array}$ \\
\hline 3 & $70 \mathrm{M}$ & 141 & 6.9 & $\begin{array}{l}\text { Low phosphate, proximal } \\
\text { muscle weakness }\end{array}$ & $\begin{array}{l}\text { Carcinoma of prostate, receiving } \\
\text { stilboestrol }\end{array}$ \\
\hline 4 & $59 \mathrm{~F}$ & 128 & $39 \cdot 6$ & ? Hypothyroid & $\begin{array}{l}\text { Ex-toxic; }{ }^{131} \text { I in } 1975 \text {. Receiving } \\
\text { thyroxine replacement known to be } \\
\text { inadequate }\end{array}$ \\
\hline 5 & $64 \mathrm{~F}$ & 117 & $5 \cdot 8$ & Glomerulonephritis & $\begin{array}{l}\text { Receiving thyroxine, TSH known to be } \\
\text { raised on this dose }\end{array}$ \\
\hline $\begin{array}{l}6 \\
7 \\
8\end{array}$ & $\begin{array}{l}69 \mathrm{~F} \\
49 \mathrm{~F} \\
28 \mathrm{~F}\end{array}$ & $\begin{array}{l}103 \\
151 \\
114\end{array}$ & $\begin{array}{r}28 \cdot 8 \\
7 \cdot 0 \\
5 \cdot 2\end{array}$ & $\begin{array}{l}\text { Weight gain } \\
\text { ? Myxoedema } \\
\text { Postoperative }\end{array}$ & $\begin{array}{l}\text { Receiving thyroxine } \\
\text { Post }{ }^{131} \text { I treatment, now on thyroxine } \\
\text { After partial thyroidectomy for colloid } \\
\text { goitre }\end{array}$ \\
\hline 9 & $47 \mathrm{~F}$ & 99 & $16 \cdot 7$ & ? Hypothyroid & $\begin{array}{l}\text { Formerly toxic; thyroid surgery } 1955, \\
131 \text { I in } 1973 \text {. Receiving thyroxine, } \\
\text { known to have a raised FBG value }\end{array}$ \\
\hline 10 & $63 \mathrm{~F}$ & 123 & $12 \cdot 3$ & Hypercalcaemia & TSH previously raised; ultrasonography \\
\hline $\begin{array}{l}11 \\
12\end{array}$ & $\begin{array}{l}55 \mathrm{~F} \\
? \mathrm{~F}\end{array}$ & $\begin{array}{l}101 \\
181\end{array}$ & $\begin{array}{r}29 \cdot 3 \\
5 \cdot 7\end{array}$ & $\begin{array}{l}\text { ? Hypothyroid } \\
\text { Receiving thyroxine }\end{array}$ & $\begin{array}{l}\text { Sample referred from another hospital } \\
\text { Sample referred from another hospital }\end{array}$ \\
\hline
\end{tabular}


Table 5. Results of TSH analyses on samples where only total thyroxine was originally requested and performed

\begin{tabular}{lll}
\hline TSH result $(\mathrm{mU} / \mathrm{l})$ & \multicolumn{2}{c}{$T_{\mathbf{4}}$ result $(\mathrm{nmol} / \mathrm{l})$} \\
\cline { 2 - 3 } & $81-90$ & $91-100$ \\
\hline $0 \cdot 1-5 \cdot 0$ & 72 & 106 \\
$5 \cdot 1-10 \cdot 0$ & 5 & 1 \\
$10 \cdot 1-15 \cdot 0$ & & 1 \\
$15 \cdot 1-20 \cdot 0$ & & 2 \\
$>35$ &
\end{tabular}

and the patients' notes were available there was either known thyroid disease or a change in binding protein values. Had this relevant information been given on the request form the TSH would almost certainly not have been cancelled.

The further analysis of the samples on which only $\mathrm{tT}_{4}$ was requested and performed showed that eight of these patients had known thyroid problems. Five were geriatric admissions with hypothyroidism which was known to have been untreated or undertreated. One particular patient (case 7) was receiving amiodarone, which affects thyroid hormone metabolism; because of his unstable heart condition the clinicians did not wish to stop the amiodarone or treat him with thyroxine.

The two other cases in this group with raised TSH values remain unexplained. In both cases the TSH increase was slight, and later thyroid function tests were all normal. A transient physiological rise in TSH may have occurred.

A review of 2000 requests for thyroid hormone measurement showed that in no case had the clinician indicated that a patient was receiving exogenous oestrogens; for practical purposes it was assumed that women between the ages of 16 and 35 might be using oral contraceptives, and TSH was measured whenever the $\mathrm{tT}_{4}$ was below $100 \mathrm{nmol} / 1(7.8 \mu \mathrm{g} / 100 \mathrm{ml})$ in this group.

Provided that the request forms were correctly completed with information relevant to the test required, this strategy for testing thyroid function seems to have been validated. Problems arose principally from the failure of clinical staff to identify those patients with known hypothyroidism, especially when this was not the prime cause of attendance at hospital.

In general, the clinical staff seem satisfied with these arrangements. A cancelled test can easily be reinstated by note or telephone. Samples are stored frozen for three months, which allows adequate time for rerequesting, provided that the clinician examines results when they are returned rather than at the patient's next appointment. As each request form is scrutinised in the laboratory it is possible for special requests to be made; "TSH regardless" or similar comment will ensure that a test is not cancelled.

We thank Miss S von Borcke and Mr N Morris for their help with the analyses, Drs D Freedman and $N$ Ellis, whose cancellations and requests comprised most of those under scrutiny.

Requests for reprints to: Mrs CM Corns, Courtauld Institute of Biochemistry, Middlesex Hospital Medical School, Mortimer Street, London W1P 7PN, England.

Table 6 Results and clinical information on patients on whom only total thyroxine was requested and initially measured who were later found to have raised TSH values

\begin{tabular}{|c|c|c|c|c|c|}
\hline \multicolumn{6}{|c|}{ Patient details } \\
\hline No & Age and sex & $t T_{4}$ & $T S H$ & Details on form & Information from notes \\
\hline 1 & Over $80 \mathrm{M}$ & 92 & $19 \cdot 1$ & $\begin{array}{l}\text { Cerebrovascular accident, } \\
\text { diabetes mellitus }\end{array}$ & Hypothyroid, not taking tablets \\
\hline 2 & $79 \mathrm{~F}$ & 91 & $5 \cdot 4$ & Falls, diuretics & $\begin{array}{l}\text { History of myxoedema; currently not } \\
\text { being treated, but has been taking } \\
\text { thyroxine in the past }\end{array}$ \\
\hline 3 & $87 \mathrm{M}$ & 81 & $5 \cdot 7$ & Myocardial infarct & $\begin{array}{l}\text { Previously raised TSH noted but no } \\
\text { action taken }\end{array}$ \\
\hline $\begin{array}{l}4 \\
5\end{array}$ & $\begin{array}{l}53 \mathbf{F} \\
33 \mathbf{F}\end{array}$ & $\begin{array}{l}80 \\
91\end{array}$ & $\begin{array}{r}7 \cdot 8 \\
10 \cdot 8\end{array}$ & $\begin{array}{l}\text { Loin pain } \\
\text { Joint pains }\end{array}$ & $\begin{array}{l}\text { Taking } 0.1 \mathrm{mg} \text { thyroxine/day } \\
\text { Microsomal and thyroglobulin } \\
\text { antibodies present }\end{array}$ \\
\hline 6 & $20 \mathrm{M}$ & 89 & $6 \cdot 7$ & $\begin{array}{l}\text { Raised prolactin, receiving } \\
\text { bromocriptine }\end{array}$ & $\begin{array}{l}\text { TSH on three previous occasions in } \\
1984 \text { were all normal; subsequent } \\
\text { result also normal }\end{array}$ \\
\hline 7 & $80 \mathrm{M}$ & 99 & $36 \cdot 7$ & Supraventricular tachycardia & $\begin{array}{l}\text { Receiving amiodarone; previously } \\
\text { raised TSH noted; cardiologists } \\
\text { unwilling to treat with thyroxine due } \\
\text { to cardiac condition }\end{array}$ \\
\hline $\begin{array}{l}8 \\
9\end{array}$ & $\begin{array}{l}78 \mathrm{~F} \\
61 \mathrm{~F}\end{array}$ & $\begin{array}{l}84 \\
92\end{array}$ & $\begin{array}{r}8 \cdot 2 \\
45 \cdot 1\end{array}$ & $\begin{array}{l}\text { Anaemia, dyspepsia } \\
\text { Hypocalcaemia }\end{array}$ & $\begin{array}{l}\text { Taking } 0.15 \mathrm{mg} \text { thyroxine/day } \\
\text { TSH grossly raised for one year after } \\
\text { partial thyroidectomy for parathyroid } \\
\text { adenoma; clinically euthyroid } \\
\text { therefore remains untreated }\end{array}$ \\
\hline 10 & $32 \mathrm{~F}$ & 88 & $8 \cdot 5$ & Secondary amenorrhoea & $\begin{array}{l}\text { No explanation; amenorrhoea } \\
\text { resolved spontaneously }\end{array}$ \\
\hline
\end{tabular}

